\title{
'How can you say to me I am a King?': New Historicism and its (Re)interpretations of the Design of Kingly Figures in Shakespeare's History Plays
}

\begin{abstract}
The 1980's saw the emergence of New Historicist criticism, particularly through Stephen Greenblatt's work. Its legacy remains influential, particularly on Shakespearean Studies. I wish to outline New Historicist methodological insights, comment on some of its criticisms and provide analytical comments on the changing approach to historical plays, asking "What has New Historicism brought into our understanding of historical plays and the way(s) of designing kingly power?" Examining Shakespeare's second tetralogy, I will review Greenblatt's contention that these plays largely focus on kingly power and its relationship to "subversion" and "containment". I intend to focus on aspects of the plays that I believe have not received enough attention through New Historicism; particularly the design of the kingly figures.
\end{abstract}

Keywords: New Historicism, Shakespeare history plays, power, disguise, estrangement, ritualism

\section{New historicism and Shakespeare studies}

If you closely examine the relationship of literary theory to Shakespeare studies during the last four decades, no theory can be credited with more impact than that of New Historicism. This approach brought to the discipline a wealth of valuable studies and irrevocably altered the historical sensitivity of all Shakespearean scholars, including those working with alternative methodological frameworks. Nevertheless, New Historicism (and New Historicists) have provoked vehement criticism ${ }^{1}$, which however, has only served to deepen our

* University of Warsaw, Poland.

1 Regarding Shakespearean studies, some of these criticisms arose within New Historicists themselves, such as Lee Patterson (xi), seeking to reject the assimilation of the historical into the textual, which I shall shortly outline. Latter day opponents include the Presentist movement who believe that criticism should not only consider 
understanding of the complexity of literature read against its (new) historical context. Furthermore, it is with the passing of time that has enabled us to better see the historical positioning of New Historicism itself, for example, its ideological debts to earlier approaches or doctrines (Marxism in particular) and its relation to latter day inquiries, such as post-postmodernism and metamodernism. Consequently, viewed through the lenses of the twenty-first century, New Historicism appears to be a "complete" methodology when it comes to defining its aims, methods and ultimate results. ${ }^{2}$ This is also why the contribution of New Historicism to contemporary understanding of some specific aspects of Shakespeare's oeuvre can be better seen and more accurately assessed.

When assessing a literary work, New Historicists insist that attention be given to the historical context that governs the works' composition. Their analysis subsequently centres around a set of fundamental premises. ${ }^{3}$ Firstly, their way of understanding literature is solely through the cultural and societal circumstances which enable that work to be written, or as H. Aram Veeser states when assessing New Historicism's "key assumptions," that "every expressive act is embedded in a network of material practices" (xi). Literature cannot also be seen as something that exists independently of history; they nonetheless reference each other, as Louis Montrose notes: "the newer historical criticism is new in its unproblematized distinctions between 'literature' and 'history"' (18). New Historicism also acknowledges that societal, cultural and political forces are responsible for the construction of human identity. Furthermore, human nature cannot be viewed as something which "rises above" history. This means that there can be no diachronic assessment of human nature between a man of the sixteenth century, for example, and ourselves as contemporary readers. History is therefore viewed as a sequence of divisions, a synchronic assessment between each era of humankind. Finally, as Louis Montrose notes, New

a literary text's past but equally refer to the critics present time in which the text is being analysed (see Hawkes and O'Grady Ed., 2006). Neema Parvini (Shakespeare and New Historicist Theory 115-132) provides a comprehensive assessment of these opponents.

2 Some New Historicists themselves have debated whether New Historicism can be regarded as a complete methodology (see Greenblatt and Gallagher, 1-19). Furthermore, Michael Payne and Jessica Rae Barbera (484) claim that New Historicism has been unable to clearly define its aims. Despite such questioning, what is important to consider is the view, supported by Parvini, that New Historicism does have value as a critical mode (Shakespeares History Plays 29). What I believe is the key appeal of New Historicism, is the impressive collection of the often provocative and unexpected readings it has achieved.

3 I am indebted to H. Aram Veeser's assessment of New Historicism (ix-xvi). 
Historicism is concerned with what he calls "the textuality of history," which he goes onto describe as a situation where "we can have no access to a full and authentic past, a lived material existence, unmediated by the surviving textual traces of the society in question" (20). This means that a historian is forever located within their own 'historicity' and that a contemporary reader cannot possibly appreciate a text in the same manner as the text's initial readership appreciated it.

It is Catherine Belsey who takes New Historicism to task for this belief in 'historicity.' Subsequently, she believes that the most a New Historicist analysis of literature can aspire to is to "use the text as a basis for the reconstruction of an ideology" (Critical Practice, 144). Nonetheless, it is this early declaration by Belsey which points to the desires of those contemporary New Historicist scholars to discover, formulate and illuminate the ideologies of the cultural and societal milieu within which writers and poets, such as Shakespeare, had worked.

New Historicist criticism has particularly flourished within the field of Shakespearean Studies ${ }^{4}$ and it is Stephen Greenblatt's work that I feel is of important relevance to my investigation of the playwright's historical plays. Noted for his seminal work Renaissance Self-Fashioning: From More to Shakespeare (1980), I would specifically like to draw attention to the essay "Invisible Bullets: Renaissance Authority and its Subversion"-first appearing in 1981 and revised in 1985 and $1988^{5}$ - an examination of Shakespeare's second tetralogy of history plays from Richard II through to Henry IV Parts 1 and 2, and finally, to Henry V. Here, Greenblatt emphasises his belief that these plays deal with kingly power and the relationship of power with notions of "subversion" and "containment". Therefore, historical plays, he insists, are not merely "a perfectly orthodox celebration of legitimacy and order" ("The Power

${ }^{4}$ See Louis Montrose's The Purpose of Playing Shakespeare and the cultural politics of the Elizabethan theatre (1996), and his analysis of A Midsummer Night's Dream. Also see Stephen Orgel's Authentic Shakespeare (2002), exploring the idea of understanding Shakespeare less as a genius than as a clue to the conjunction of the world of the English Renaissance theatre and the complex social politics of the time, asking us to consider what the authentic text of a Shakespeare play really represents.

5 See S. Greenblatt, "Invisible Bullets: Renaissance authority and its Subversion," Glyph 8 (1981): 40-60. Then, "Invisible Bullets: Renaissance authority and its subversion, Henry IV and Henry $V^{\prime}$ ' in Political Shakespeare: Essays in Cultural Materialism. Ed. J. Dollimore and A. Sinfield. Manchester: Manchester University Press, 1985: 18-47. Finally, see "Invisible Bullets," in S. Greenblatt, Shakespearean Negotiations: The Circulation of Social Energy in Renaissance England. Berkeley and Los Angeles, California: University of California Press, 1988: 21-65. 
of Forms", 1444). Kingship continually involves the creation of subversion and disorder to contain and maintain power over its subjects.

In my desire to ask, "What has New Historicism brought into our understanding of historical plays and the way(s) of designing kingly power?", I am also drawn to the critical reaction towards Greenblatt's observations and interpretations. ${ }^{6}$ It is my belief that these critics do not actually reject Greenblatt's views because their own construction of their readings of the second tetralogy use the same ideological message as Greenblatt, often using the same passages from these plays to clarify their views. Therefore, I believe that these responses can be incorporated into an analysis of Shakespeare's historical plays, making my essay not only a recapitulation of Greenblatt's contribution but also an overview of the critical response to the plays in the wake of Greenblatt's analyses.

My analysis focuses, too, on one of the effects of Greenblatt's emphasis on subversiveness, which is the consistent critical focus on the modes of presenting the king in relation to his subjects. Subsequently, I wish to show how the audience's design of a model of kingship contains the modes of ritualism, estrangement (by the use of soliloquy) and disguise (used to emphasise the desire for true interaction between a king and his subjects) that characterise the relationship of the kings to his subjects.

6 As this essay focuses on Greenblatt's initial readings of the Second Tetralogy and assessing how those critical responses embraced these readings, I also acknowledge Greenblatt's later examination of Henry $V$ in "Shakespeare and the ethics of authority." Shakespeare's Freedom (2012, 74-94) where he contends that Henry V is probably the closest Shakespeare ever came to representing the authority of the ruler as divinely sanctioned. Regarding the critical reaction, David Kastan argues that "neither the history play nor history itself in fact gives much evidence that containment is ever as efficient or complete as [Greenblatt's] reading insists. If subversion were always produced by and for power, power would always remain unchallenged and intact; but Henry IV's very presence on the throne argues otherwise" (38). Catherine Belsey advocates that such theories of subversion and containment "take account of the possibility of resistance, not simply as power's legitimation, its justification or glorification, as the new historicists seem so often to argue, but as its defining, differentiating other, the condition of its existence precisely as power" (Shakespeare in Theory and Practice 136). Terence Hawkes also summarises the tensions within New Historicists coming to terms with the theory of subversion and containment, noting their reluctance to accept containment as a "generalized condition of power" but rather opting for an "ideological containment" working in "such a paradoxical and cunning fashion in some local and historically specific instances." (Alternative Shakespeares, 27). 


\section{An enfeebled state}

In "Invisible Bullets: Renaissance Authority and its Subversion", Greenblatt introduces the concept of subversion and containment as an instrument of power by focusing on Thomas Harriot's report made in 1588, A Brief and True Report of the New Found Land of Virginia. This report, Greenblatt claims, is professing quite an "orthodox religious faith" (21). However, he then questions Harriot's orthodoxy by referring to his reputation of being an atheist. While being unable to prove this, Greenblatt remains confident that the connection between Harriot's professed orthodoxy and his reputation for subversive atheistic practices are evidenced in the report itself. It is through understanding this connection, Greenblatt adds, that has important relevance in our understanding of the history plays of Shakespeare (23).

A brief examination is then conducted of the differing ideological "strategies" that have been historically attributed to Shakespeare's history plays. It is these strategies, Greenblatt adds, that "fashion Shakespeare's history plays [which] help in turn to fashion the conflicting readings of the plays' politics" (23). Such blueprints, he continues, are evident in Harriot's report, where we witness "the discourse of authority," containing within it "a powerful logic [which] governs the relation between orthodoxy and subversion" (23).

Greenblatt goes on to point out the ambiguous status of Harriot in contemporary culture, examining rumours of the mathematician's atheism and being a "juggler", a member of a conspiracy imposing a new religion (41). A description is given by Greenblatt of the misinterpretations by the Indians of the power and status of the invaders and the way these subversive accounts are "contained" by making, for example, the overall technological superiority of the Europeans an expression of God's will. Such misinterpretations are therefore used to manipulate the Indians into believing in the divinity of those who possess it. This, for Greenblatt, is the first strategy of "the testing of a subversive interpretation of the dominant culture" (35). Greenblatt then describes how the Indians tried to account for the occurrences perpetuated by the newcomers' presence, looking at, for instance, the spread of disease and the resulting death of the tribes. This strategy he calls "the recording of alien voices or more precisely, of alien interpretations" (35). Greenblatt contends that both strategies are at work in Shakespeare's histories which make them reinforce the Tudor orthodoxy and - at the same time - appear dangerously radical. ${ }^{7}$ This theory, Greenblatt adds, immediately implies maliciousness and Machiavellian callousness but this is not always the case, and he takes pains to stress that Harriot may not have been acting maliciously. Hence, we arrive at how Greenblatt named his essay,

7 Jonathan Bate believes that Greenblatt's analysis is somewhat flawed and "flattens" the complexity of the political and religious upheavals of the Tudor dynasty (341). 
derived from Harriot's report and referring to "the invisible bullets", for instance, the way the English inflicted diseases and misfortune on the hostile tribes. Originally the expression was to render the unexplainable nature of the weapons used by the newcomers. Paradoxically, however, modern knowledge about the spread of viruses and bacteria renders this comparison very accurate.

In his attempt to theorize this mechanism and arrive at the general dictum that subversion is invisible to the targeted audience, Greenblatt states that Shakespeare's history plays are "centrally, repeatedly concerned with the production and containment of subversion and disorder" (40). With these views in mind, I shall now begin my investigation of one of the plays that focuses on the consolidation of state power, Richard II. This will include an assessment of Greenblatt's comments on the play which I believe clarify his own position on the nature of this king's power and authority.

There is a further conviction that "the representation of a selfundermining authority" is the predominant issue of Richard II ("Invisible Bullets," 40). Greenblatt is responding here to the concept of (sacred) kingship in Richard II which had already received much critical attention, further augmented by the work of Ernst Kantorowicz's The King's Two Bodies (1957). ${ }^{8}$ However, it is the potentially subversive nature of Richard's auto-reflexive comments and intimate confessions, followed by various containment strategies which are the focal point of Greenblatt's inquiry. Traces of similar emphasis on the oscillation between subversion and containment can be also found in the critical commentaries of other scholars, writing in the wake of Greenblatt's analysis.

From the outset, as Charles Forker notices, we are made aware of Richard's volatile personality (180). This king has difficulty identifying who he is, from the pronoun "Tell me moreover" (1:1:8) to "Yet one but flatters $u s$ " (1:1:25). Nonetheless, there is already a system at play where this king can be designed - through systematic, ritualistic ruling routines. The argument between Bollingbroke and Mowbray is testament to this ritualism, where soldiers' gloves (or gages) are repeatedly thrown to the floor, signifying challenges to each other's beliefs. Richard himself uses a kingly tool through which he believes can exercise power, and indeed, grant privileges to his subjects:

KING RICHARD: Now, by my sceptre's awe, I make a vow Such neighbour nearness to our sacred blood Should nothing privilege him nor partialize The unstooping firmness of my upright soul. He is our subject, Mowbray; so art thou Free speech and fearless I to thee allow. (1:1:118-123)

${ }^{8}$ See The Shakespeare: King Richard II, Kantorowicz, 1957. 24-41. 
What is striking about this passage is that the entire scene-with the aggravating conflict of Bolingbroke and Mowbray-signals the inevitable beginning of Richard's downfall. Bolingbroke attacks Mowbray for what Richard had done to Gloucester, whereas the only way for Mowbray to defend himself is to reveal Richard's guilt. Thus the scene is subversive because it shows how the king (guilty of what he is accused of) defends himself with a recourse to ritualism (evoking the concept of sacred blood, threatening Bolingbroke for the sake of royal justice, and projecting the image of a benign and fair ruler, for example, to speak freely, be fearless) while in fact he wants both of them to be silent. Exposing the hypocrisy of the ruler is potentially subversive and discredits the arguments and formulas used by Richard. And yet, this subversiveness is also contained (similarly as in the case of Harriot's justification of deluding the Indians) by the ultimate course of history: the rebellion leads to Richard's deposition, the deposition to his murder, and his murder to the war of the roses, and therefore to the destruction of many lives and the ruin of the country.

Richard's superiority lies exclusively in his language which renders most of the arguments he uses about sacred kingship entirely empty, a claim particularly risky from the point of view of Tudor royalist doctrines. Again, the subversive, radical nature of this reading is counterbalanced by the portrayal of Henry IV and his sense of guilty conscience. Neema Parvini, conducting his own reading of Richard II very much in line with Greenblatt's general assumption about the recurrent pattern of subversion and containment, states that if Richard means to exercise power, to contain it through such ritualism, we cannot ignore Richard's method of asserting that ritualistic grasp of power through language. This is exemplified, Parvini adds, in Richard dictating the poetic form of the language to control his subjects (Shakespeare's History Plays, 184). This is achieved when the king breaks Mowbray's use of rhyming couplets:

MOWBRAY: In haste whereof most heartily I pray Your highness to assign our trial day.

KING RICHARD: Wrath-kindled gentleman, be ruled by me.

Let's purge this choler without letting blood. (1:1:150-153)

It is through, however, such beliefs in ritualistic power and this conception of language which bring about this king's "undoing". As Parvini notes while aligning himself to Greenblatt's view that Richard self-undermines his authority, the king becomes over-reliant on his convictions of power and language which later emphasises his inability to act, showing how ideology becomes ineffective if not supported by physical action (Shakespeare's History Plays, 190).

Soon, Richard begins to strip away his royal vestige, his protections, rituals and theatricalities and confront the bare reality of his existence: 
KING RICHARD: ...Throw away respect,

Tradition, form and ceremonious duty

For you have mistook me all this while.

I live with bread like you, feel want,

Taste grief, need friends. Subjected thus,

How can you say to me I am a king ? (3:2:172-177)

From a very public design of the king, we become witness to Richard's more private thoughts while in captivity, typifying his estrangement from his subjects, his state, and indeed, his self. This leads to a greater, more intimate relationship in the sharing of a "kingly" consciousness (albeit a deposed one) with the audience. In the use of soliloquy, Richard begins to achieve a degree of self-awareness:

KING RICHARD: Learn, good soul,

To think our former state a happy dream,

From which we awaked, the truth of what we are

Shows us but this. $(5: 1: 17-20)$

In undermining his own authority, Richard becomes a personification of Greenblatt's idea of a power producing its own subversion and yet we see a king becoming more identifiable as a subject playing the king. We are privy to his weaknesses and in being so, we bring a king (and his thoughts) much closer to the thoughts of us, the audience, more than ever before.

\section{The usurper King and his prodigal son}

As Neema Parvini notes, Henry Bollingroke at the beginning of Henry IV Part 1 is not particularly fond of the ritualism of Richard II's court, but rather, a more systematic, indeed "business-like" approach to power, reflected in a language underpinned by expediency (Shakespeare's History Plays, 191). Such an example is exhibited in Bollingbroke's desire for the Crusade to Jerusalem:

KING: Cousin, on Wednesday next our Council we Will hold at Windsor. So inform the Lords.

But come yourself with speed to us again.

For more is to be said and to be done

Than out of anger can be uttered. (1:2:100-106)

Ultimately, the King seems to create an ideology that creates virtue out of action. This view is enforced later in Henry IV Part 2, when he advises his son: 
KING: ...to busy giddy minds

With foreign quarrels, that action hence borne out

May waste the memory of the former days. (4:5:213-215)

And yet it is his son, Hal, who Greenblatt believes provides the means to solidify authority, to reclaim it from an enfeebled and self-undermining state ("Invisible Bullets", 40-41). His image, Greenblatt contends, "involves as its positive condition the constant production of its own radical subversion and the powerful containment of that subversion." (41) Furthermore, Hal has a clear strategy in his method of kingly design. It is laid out in his soliloquy, a feigned plan of estrangement from how a future king should typically behave:

PRINCE: I know you all, and will uphold

The unyoked humour of your idleness.

Yet herein will I imitate the sun. (1:2:185-187)

As Richard II was able to do, Hal is also able to share his intimate thoughts with the audience, revealing his estrangement (whether real or feigned). In addition, we see an identification between the two protagonists as roleplayers, the actor who would be king (Hal) and the former actor king (Richard).

To achieve and solidify power around himself, Greenblatt contends that Hal must "record" the discourses of those he socialises with in the London taverns (45), and this is encapsulated in his relationship with Sir Jack Falstaff. David Kastan believes the old knight to be a threat, again conjured by the "juggler" Hal, "to necessitate the exercise of rule", where Hal is demonstrating a use of power to compel others without apparent coercion, to serve "the interests of the dominant power" (Kastan 36). And so, Hal and Falstaff play out an extraordinary scene intended to amuse themselves, becoming largely comedic to the audience, seemingly demonstrating this exercise of rule. ${ }^{9}$ As the scene climaxes, Hal chillingly responds to Falstaff, confirming this Prince's intention to redeem himself to the legitimacy of his regal role:

FALSTAFF: ... valiant Jack Falstaff, [...] banish not him thy Harry's company. [...] Banish plump Jack, and banish all the world. $[\ldots]$

PRINCE: I do; I will. (2:4:463-467)

9 Edward Pechter is among those critics who feel that Falstaff deserves greater consideration in the second tetralogy. Noting Greenblatt's avoidance of the character as one of the play's "other voices," it is Falstaff's, Pechter contends, which is "part of [Henry IV Part 1's] insistence" (294). Were it the playwright's intention in doing this, it could be argued that it is Falstaff himself who is containing Hal in this scene and not vice versa. David Kastan also adopts a similar view and I will introduce this in my conclusion here. 
Daniel Colvin reminds us that Hal is not only a master role-player but also uses the function of disguise to great effect, representing another mode which initially aids $\mathrm{Hal}$ in his redemptive strategy (49). Colvin asks us to view Hal's role-playing and disguise with Greenblatt's own theory of "selffashioning", a term introduced in his Renaissance Self-Fashioning (1980), used to describe the process of constructing one's identity and public persona, usually by society's upper-classes, according to a set of socially acceptable standards (53). Hal's disguise is noted in the Gadshill robbery, where himself, Falstaff and Poins, conspire to rob some travellers, providing the means for further revels and mischief. Previously objecting to the idea, Hal later agrees to Poins' practical joke to rob the robbers. Hal enjoys the robbery as the joke is realised. As Colvin notices, this enjoyment also underlines Hal's "ability to fashion himself in whatever disguise he wishes" (53). Indeed, Hal is far from discarding his uses of disguise as we later see when assuming the crown.

In the meantime, as King Henry draws his armies towards the Battle of Shrewsbury, we finally see a king and his errant son on stage together. Hal is clearly intent on revealing his redemptive strategy, promising to banish his dubious past and to be "more myself" (3:2:95). Colvin notices, though, that all of Hal's roleplaying has taken its toll; "the pattern of disguise presented in the play subverts the audience's ability to believe in an essential identity in Hal. Strip off all his layers of disguise, of self-fashioning, and there would be no Hal." (54) You begin to wonder the nature of the self-identity Hal desires and what indeed the audience is also attempting to reconstruct, of a would-be king.

Hal himself, as Greenblatt notes, is less calculating in Henry IV Part 2 ("Invisible Bullets", 48). There is no need for him to return to his redemptive strategy as he had already revealed it in pledging allegiance to his father. Nevertheless, the propensity to role-play, to disguise, are still evident. This is typified when Hal and Poins plan to reveal themselves to Falstaff in Eastcheap, concealed as drawers. When Hal eventually does so, enraged by Falstaff's less than flattering description of the Prince, we are further reminded that the authority is seemingly producing and containing the subversion:

PRINCE: I shall drive you to then confess the wilful abuse, And then I know how to handle you.

FALSTAFF: No abuse, Hal, o' mine honour, no abuse.

PRINCE: $\quad$ Not ?- to dispraise me, and call me pantler, and Bread-chipper [...] ? (2:4:308-312)

Witnessing his dying father, Hal returns to soliloquy, a moment where Greenblatt contends, the future king is "seeking to merge his body into the body of the state" (55). It is a moment which also confirms an estrangement from his father as he focuses on designs of obtaining the crown: 
PRINCE: My due from thee is the imperial crown, Which, as immediate from thy place and blood,

Derives itself to me. [Putting it on his head] Lo where it sits, Which God shall guard; and put the world's whole strength Into one giant arm. (4:5:40-44)

Hal takes the crown and soon, the dying King realises it is missing. This event confounds his belief that his son has honourable intentions, clearly dismayed that he has already sought advances on the crown. In his own soliloquy his estrangement from the truth of his son's intentions, is marked in:

KING: ...see, sons, what things you are, How quickly nature falls into revolt When gold becomes their object ! (4:5:64-66)

In his final moments, we are witness to Henry's abdication, almost the antithesis to the theatricality and poetry of Richard's self 'un-kinging'. One cannot help but feel, as Neema Parvini suggests (Shakespeares History Plays, 202), that the King has no control over language, no ear for the poetical forces of language which have failed him in his struggle to exercise rule:

KING: Give that which gave thee life unto the worms;

Pluck down my officers: break my decrees;

For now a time is come to mock at form-

Henry the Fifth is crown'd ! (4:5:115-119)

The newly-crowned King is quick to rid himself of his former retinue, achieved in a dramatic fashion by his rejection of Falstaff, one prophesied, as we saw, in the Eastcheap play extempore:

KING: Presume not that I am the thing I was:

For God doth know, so shall the world perceive,

That I have turn'd away my former self;

So will I those that kept me company. (5:5:56-59)

Hal as King is still alluding to his penchant for roleplaying and disguise as he embraces his kingly role. At this point, Greenblatt feels, perhaps as the audience does, dissatisfaction at the conclusion of the play ("Invisible Bullets," 55-56). And yet, he adds, this dissatisfaction is indicative of "a carefully plotted official strategy" whereby subversive impressions are immediately generated and "contained" (56). This is exemplified when Hal states: 
KING: ...I survive,

To mock the expectation of the world,

To frustrate prophecies, and to raze out

Rotten opinion. (5:2:125-128)

In this sense it is the kingly ability to alter and sustain his own design(s) as a figure of power which ensures the effectiveness of exercising authority.

\section{The King unified in body and state}

Greenblatt feels that Henry IV compels the audience, likened to those native Indians referred to in Harriott's account, "to pay homage to a system of beliefs whose fraudulence only confirms their power, authenticity and truth" (56). In Henry $V$, however, Greenblatt contends we are now no longer worshipping that system but are somewhat infused into it, realizing we "have all along been both colonizer and colonized, king and subject" (56). The play begins with a prologue, which Greenblatt feels not only outlines Hal's claim to the throne, but also an "ideological justification of English policy" (60). The succeeding Choruses also serve to enforce Greenblatt's contention that understanding a historical play involves the audience's active imagination in reconstructing it:

CHORUS: And let us, ciphers to this great account,

On your imaginary forces work. (Prologue: 37-38)

Furthermore, Greenblatt contends that the play tests the idea that competent rule depends as much on "demonic violence" as sacredness. This is achieved in "the context of a celebration, a collective panegyric to "This Star of England"" (56). We should not be surprised that Hal is capable of being part of this celebration, for creating it, as he has been the supreme role-player all along. Daniel Colvin reminds us, invoking Greenblatt's theory, that while becoming Henry V, Hal has achieved this through self-fashioning (53). ${ }^{10} \mathrm{Hal}$ 's

${ }^{10}$ Colvin's analysis of Hal/Henry V's self-fashioning is far from comprehensive and he is quite dismissive of Greenblatt's contention that self-fashioning resides in language (53). Rather than simply acknowledging Hal's self-fashioning mainly through a use of attire, as Colvin does, this is a character who is also fashioned through his hubristic and often violent rhetoric. There also needs to be an embracing of the vulnerability of the Prince/King as a self-fashioning subject, taking on these rhetorical modes. I have undertaken a greater study of Hal and his self-fashioning as part of my doctoral thesis (Dale, James. "Incognitos: Shakespeare's Uses of Disguise in the Light of New Historicism and Its Legacy." Diss. University of Warsaw, 2021). 
kingly self is seemingly a forthright, hubristic and ultra-confident one, providing authority which Richard II had lost and certitude in the face of Henry IV's equivocation. It marks the apotheosis of Greenblatt's earlier claim for Hal that the future king's appearance begins to mark the consolidation of the King's reclaimed authority.

Greenblatt wishes to remind us of Hal's cold-bloodiness as the new King rejects his old Eastcheap companions. Bardolph, is summoned to execution and the most notable, Falstaff, is dealt with, Greenblatt contends, "as the climatic manifestation of [Hal's] virtues." ("Invisible Bullets", 58). He notices that the very utterance of the old knight triggers the triumphal entrance of the new King to become symbolic of "a potential discourse being absorbed into a charismatic celebration" (58). For Greenblatt, such betrayal only helps preserve the status quo of moral authority, together with its network of power relations. That authority, he adds, "is precisely the ability to betray your friends without stain" (58). However, it is not conclusive in my view whether we can consider Falstaff as Hal's friend, as Greenblatt asserts. Hal never makes any vows of friendship and in this 'play extempore,' Hal - in the role of his father, or King - rejects Falstaff.

Nonetheless, the compelling spectacle of power, its theatricality, solidified in what seems a strident, confident king, receives its apotheosis in his battle of Agincourt's war-cry:

KING: [...] when the blast of the war blows in our ears,

Then imitate the action of the tiger,

Stiffen the sinews, conjure up the blood.

Disguise fair nature with hard favoured-rage. (3:1:4-8)

"Disguise", "imitate", "conjure up", remind us that our role-player Prince is still very much now the role-player King, advising his subjects to selffashion their way as victorious warriors.

Later, in a bid to rally his beleaguered men, and to seek a truer interaction with his subjects, Hal dons disguise once more, borrowing the cloak of Sir Thomas Empingham to gauge his soldiers' mood. He encounters Bates and Williams and provides them with an opinion of the one disguised:

KING: I think the King is but a man, as I am:

The violet smells to him as it doth to me; the element

Shows to him as it doth to me; all his senses have but

Human conditions. (4:1:102-105)

In the desire to truly interact with his subjects, Hal, as he did in Eastcheap, is trying to record the prose discourse that the two soldiers speak. 
Hal later acknowledges that Richard II's ingratiating ritualism proved worthless, the ideals of such a system estranged from not only himself but the everyday realities of his subjects:

KING: I am a king that find thee and I know

'Tis not the balm, the sceptre and the ball,

$[\ldots]$

Not all these, laid in bed majestical,

Can sleep so soundly as the wretched slave,

Who with a body filled and vacant mind

Gets him to rest. (4:1:256-266)

Greenblatt concludes his assessment of Henry $V$ by saying that an ideal king "must be in large part the invention of the audience" (63) and that power belongs to people who can command and profit from the exercising of their imagination (64). At the completion of the cycle of the second tetralogy, the design of its kings, the construct of the audience's imagination, attains its final draft. Greenblatt's conclusion here points to the belief that this king is best able to identify with his country, his subjects, more than his predecessors.

Greenblatt and New Historicism has brought into our understanding of historical plays that they are not merely a traditional celebration of a legitimate law and order, but rather, continually involve the creation of subversion and disorder to contain and maintain power over its subjects. As Greenblatt has also recognised, a New Historicist examination of these history plays has revealed that the construct of the king has been down to the invention of the audience themselves. Significantly enough, the audience's design of a model of kingship, contains the modes of ritualism, estrangement and disguise that tend to characterise the relationship of the kings to his subjects. In addition, two of Shakespeare's kings, Richard II and Henry V, revel in being actors themselves, and reveal their acting potential through a continuous juggling of the three modes of kingly design. The other king, Henry IV, in contrast, is clearly not the consummate actor and lacks the poetical forces of language while performing his role. The design of this king is largely characterised by estrangement from his subjects, his role, his nation and his son. Through soliloquy, Bollingbroke's private manifestations are felt directly by the audience, making them construct and revise their ideas of kingship, thereby seeing through public designs of royal greatness.

In accepting, like Greenblatt, that a construct of our Kings in the second tetralogy can only be an artificial one, Neema Parvini is seen to conduct, as other critics have done, a reading of the plays through Greenblatt's framework of subversion and containment, a restatement of the same ideological message. However, what Parvini goes onto stress are other factors which point beyond this 
reading of Shakespeare. One concerns this scholar's refutation of the New Historicist belief in anti-humanism (Shakespeares History Plays, 52-71), as we view our construction of Kings within the Second tetralogy on parts very much played by humans. Parvini also raises the concern that New Historicism overlooks the formal and linguistic features of these plays, wanting to uphold Shakespeare's creative independency, seeking to challenge Greenblatt's idea that Shakespeare's plays were not merely a production of Elizabethan culture and the time in which Shakespeare wrote (209).

It is these concerns that perhaps find their embodiment in the one character that Greenblatt believes has been contained all along, Sir Jack Falstaff. David Kastan believes that Falstaff does not submit to Hal, he is "the play's mark of resistance to the totalizations of power" (Kastan 43). If there is any submission on Falstaff's part, it is only to, as Kastan (43) remarks:

FALSTAFF: our noble and chaste mistress the moon, under whose Countenance we steal. (Henry IV Part 1: 1:2:26-28)

The evident, ebullient humanism and champion of the cut-purse, embracing all those corners of life, is perhaps the one thorn in Greenblatt's side for it may show that the overpowering celebration of life in one man cannot be contained by either the stage or the minds of the audience constructing his very presence.

\section{WORKS CITED}

Bate, Jonathan. The Genius of Shakespeare. New York and Oxford: Oxford University Press, 1998.

Belsey, Catherine. Critical Practice. London: Methuen, 1980.

- Shakespeare in Theory and Practice. Edinburgh: Edinburgh University Press, 2008.

Colvin, Daniel. L. "(Re)covering the Self: Hal and the Psychology of Disguise." In Staging Shakespeare: Essays in Honor of Alan C. Dessen, Ed. Lena Orlen and Miranda Johnson-Haddad. Newark: University of Delaware Press, 2007: 45-59.

Dale, James. "Incognitos: Shakespeare's Uses of Disguise in the Light of New Historicism and Its Legacy.” Diss. University of Warsaw, 2021.

Grady, Hugh and Terence Hawkes, ed. Presentist Shakespeares. London and New York: Routledge, 2006.

Greenblatt, Stephen. Renaissance Self Fashioning: From More to Shakespeare. Chicago, USA: The University of Chicago Press, 1980.

"Introduction to The Power of Forms in the English Renaissance." In The Critical Tradition: Classic Texts and Contemporary Trends. Ed. David Richter. Boston, USA: Bedford/St. Martin's, 1982: 1443-1445. 
. "Invisible Bullets." In Shakespearean Negotiations: The Circulation of Social Energy in Renaissance England. Berkeley, Los Angeles, USA: University of California Press, 1988: 21-65.

-. "Shakespeare and the Ethics of Authority." In Shakespeare's Freedom. Chicago, USA and London: The University of Chicago Press, 2010: 74-94.

Greenblatt, Stephen and Catherine Gallagher, ed. Practising New Historicism. Chicago and London: The University of Chicago Press, 2001.

Hawkes, Terence. Alternative Shakespeares, Volume 2. Abingdon, Oxford: Routledge, 1996.

Howard, Jean. "Marxism and Shakespeare." In Marx and Freud: Great Shakespeareans. Volume X, Ed. Crystal Bartolovich, Jean Howard and David Hillman. London and New York: Continuum International Publishing Group, 2012: 62-93.

Kantorowicz, Ernst. The King's Two Bodies: A Study in Mediaeval Political Theology. Princeton: Princeton University Press, 1957.

Montrose, Louis. "Professing the Renaissance: The Poetics and Politics of Culture." In The New Historicism. Ed. H. Aram Veeser. New York and London: Routledge, 1989: 15-36.

Parvini, Neema. Shakespeare's History Plays. Rethinking Historicism. Edinburgh: Edinburgh University Press, 2012.

- Shakespeare and New Historicist Theory. London and New York: Bloomsbury Arden Shakespeare, 2017.

Patterson, Lee. Negotiating the Past: The Historical Understanding of Mediaeval Literature. Madison, WI: University of Wisconsin Press, 1987.

Payne, Michael and Jessica Barbera. A Dictionary of Cultural and Critical Theory. Chichester: Wiley Blackwell, 2013.

Pechter, Edward. "The New Historicism and Its Discontents: Politicizing Renaissance Drama." PMLA, vol. 102, no. 3, (May 1987): 292-303.

Shakespeare, William. King Richard II. Arden Shakespeare Third Edition. Ed. Charles Forker. London: Bloomsbury Publishing, 2002.

- Henry IV Part One. Arden Shakespeare Third Edition. Ed. David Kastan. London: Bloomsbury Publishing, 2002.

- Henry IV Part Two. Arden Shakespeare Third Edition. Ed. James Bulman. London: Bloomsbury Publishing, 2016.

- Henry V. Arden Shakespeare Third Edition. Ed. Thomas Craik. London: Bloomsbury Publishing, 1995.

Veeser, H. Aram, ed. The New Historicism. New York and London: Routledge, 1989. 